\title{
TAVOITTEIDEN SAAVUTTAMINEN NÄKYVÄKSI TYÖLLISTYMISTÄ JA OSALLISUUTTA EDISTÄVISSÄ PALVELUISSA
}

Kansaneläkelaitos edellyttää GAS-menetelmän käyttöä kuntoutuksen tavoitteiden saavuttamisen seurannassa (Kela 2016). Rinnekoti-Säätiön työ-ja päivätoiminnassa eli työllistymistä ja osallisuutta edistävissä palveluissa ei vaadetta menetelmän käyttöön ollut. Oli kuitenkin tarve löytää sopiva työkalu tavoitteiden asettamiseen ja arvioimiseen. Vuoden 2016 aikana toteutettiinkin GAS-menetelmän käyttöönottoon liittyvä tutkimusprosessi Rinnekoti-Säätiön työllistymistä ja osallisuutta edistävissä palveluissa (Eskola 2016).

Tutkimuksessa kerättyjen kokemusten mukaan GAS-menetelmä sopii yksilöllisten tavoitteiden asettamiseen ja seurantaan myös työllistymistä ja osallisuutta edistävissä palveluissa. Menetelmä lisää asiakaslähtöisyyttä tavoitteiden asettamiseen ja tuo siten palvelunkäyttäjien ääntä enemmän kuuluville.

Tutkimusprosessin alussa Lahden Ammattikorkeakoulu järjesti täydennyskoulutuksen Rinnekoti-Säätiön henkilökunnalle. GASkoulutuksessa opittiin menetelmä, jonka avulla voidaan kehittää työllistymistä ja osallisuutta edistävien palveluiden toimintaa sekä osoittaa toiminnan vaikuttavuutta. GASmenetelmä (Goal Attainment Scaling) mahdollistaa asiakkaan yksilöllisten tavoitteiden asettamisen yhdessä menetelmän hallitsevan ammattihenkilön kanssa. Menetelmä tuo sys- temaattisen tavan asettaa ja arvioida tavoitteiden toteutumista ja mahdollistaa erinomaisen näkökulman kuntoutuksen tulosten tarkasteluun. (Laukkala, Tuomi \&t Sukula 2015.)

\section{GAS-menetelmä ratkaisuna tavoitteiden ja arvioinnin kehittämistarpeisiin}

Rinnekoti-Säätiössä on ajoittain virinnyt keskustelua siitä, että palvelunkäyttäjille asetettujen tavoitteiden arvioimiseen sopivia mittareita puuttuu. Toimintakykyarvioinnit tehdään pääasiassa TOIMI-menetelmällä. Se on tarkasteluprosessi, jossa luodaan yleiskuva henkilön selviytymisestä omissa toimintaympäristöissään ja omassa elämäntilanteessaan. Tarkastelun kohteina ovat taidot ja voimavarat sekä niiden käyttöä estävät tai haittaavat tekijät. (Kehitysvammaliitto 2014.) Kokemuksena on kuitenkin ollut, että TOIMI-menetelmä ohjaa tavoitteiden asettamista, mutta ei palvele tavoitteiden toteutumisen arviointia. Tästä johtuen aloitettiin tutkimusprosessi järjestämällä GAS-menetelmästä koulutus, kokeilemalla menetelmää työ- ja päivätoiminnan arjessa ja keräämällä kokemuksia menetelmän käyttöönotosta.

Kolmipäiväiseen koulutukseen osallistui ohjaajia eri yksiköistä: sosionomeja, yhteisöpedagogeja, lähihoitajia, toimintaterapeutteja, nuoriso- ja vapaa-ajan ohjaajia, kuvankäsitte- 
lijä, artenomi sekä kehitysvammaistenohjaaja. Koulutuksen jälkeen tutkimukseen osallistuvissa yksiköissä pidettiin infotilaisuudet, joissa sovittiin GAS-menetelmän käytöstä. Käytännön kokeilu toteutettiin esimerkkitapaustyöskentelyllä pienryhmittäin. Ohjaajien kokemukset GAS-menetelmän käytettävyydestä ja hyödynnettävyydestä kerättiin kahdella fokusryhmähaastattelulla.

\section{GAS suuntaa omaa työskentelyä kohti perustehtävää}

Kokeilun tulosten mukaan ohjaajat saivat GAS-menetelmän kokeilusta sekä positiivisia että haastavia käyttökokemuksia, joista positiiviset kokemukset olivat kuitenkin enemmistönä. Lisäksi ohjaajat saivat kokemusta menetelmän erilaisista ominaisuuksista, joita he kuvasivat tarkasti. Monet kokemukset, huomiot ja ideat ovat sellaisenaan hyödynnettävissä, mikäli GAS otetaan käyttöön työllistymistä ja osallisuutta edistävissä palveluissa. Käyttökokeilu tuotti myös monenlaisia kysymyksiä, jotka vaativat ratkaisua ennen käyttöön ottamista.

Ohjaajat kokivat GAS:n selkeäksi, helpoksi ja asiakaslähtöiseksi menetelmäksi, joka kirkastaa tavoitteita ja tekemistä. GAS:ssa ilahduttivat sen prosessiin liittyvät vaiheet: alkukartoituksen tekeminen, tavoitteiden asettaminen ja pilkkominen sekä arviointi. Tavoitteiden saavuttamisen mitattavuutta ja tulosten esiintuloa pidettiin hyvänä. Menetelmän näkyminen arjessa koettiin positiiviseksi. Tutkimuksen tulokset olivat hyvin samanlaisia kuin aiemmissa tutkimuksissa (Puhakka 2015, Sallinen ym. 2015, Tuomi 2014, Ylisassi 2012).

Menetelmän käyttöönotosta on aiemmin todettu, että se vaatii samalla tavalla harjoittelua kuin muidenkin arviointimenetelmien käyttöönotto (Autti-Rämö 2010, 16). Saman totesivat myös tutkimukseen osallistuneet. Aiemmin on myös todettu, että aluksi haasteena on varsinkin ajankäyttö ja lomakkeen täyttäminen (Sallinen ym. 2015, 14-15; Tuomi 2014, 34). Toisaalta oma motivaatio sekä kollegoiden ja työyhteisön tuki ovat edistäviä tekijöitä (Sallinen ym. 2015, 15). Mene- telmän eduiksi voidaan lukea toiminnan organisoituminen ja fokusoituminen tavoitteista yhdessä puhumisen ansiosta. Menetelmä rohkaisee moniammatilliseen keskusteluun ja yhteistyöhön ryhtymistä. (Smith 1994, 1-3.) Tämän tutkimuksen tulokset olivat samanlaisia. GAS-tavoitteiden mukainen työskentely oli suunnannut omaa työskentelyä kohti perustehtävää. Ohjaajat kokivat yhteistyön tuntuneen mukavalta ja yhteisen pohdinnan ja työskentelyn olleen rikasta.

\section{Mahdolliset kognitioon ja kommunikaatioon liittyvät ongelmat}

Tavoitteen laatiminen alkaa keskustelulla asiakkaan kanssa. Tämän jälkeen palveluntarjoaja auttaa tavoitteen muotoilussa, tavoitteelle annetaan nimi ja valitaan selkeä indikaattori, jolla tavoitteen saavuttamista mitataan. (Sukula \&t Vainiemi 2015, 14.) Moni prosessin vaihe siis vaatii kielellisiä taitoja. Näissä on työllistymistä ja osallisuutta edistävien palveluiden asiakasryhmillä usein puutteita.

Suomenkielisessä kuntouttavassa työtoiminnassa GAS koettiin helpoksi työkaluksi. Näillä palvelunkäyttäjillä onkin kielelliset edellytykset menetelmän käyttöön. Kehitysvammaisten henkilöiden työ- ja päivätoiminnassa sekä maahanmuuttajien kuntouttavan työtoiminnan ryhmissä kielelliset vaikeudet tulivat eteen kaikissa GAS:n eri työvaiheissa. Mahdolliset kognitioon ja kommunikaatioon liittyvät ongelmat onkin todettu haastaviksi tavoitteita asetettaessa (Laukkala ym. 2015, 11). Tämä tulee huomioida, mikäli menetelmä otetaan käyttöön työllistymistä ja osallisuutta edistävissä palveluissa. Tulee pohtia mahdollisuutta hyödyntää vaihtoehtoisia ja korvaavia kommunikaatiokeinoja sekä työskentelymenetelmiä. Keskustelun lisäksi alkukartoitusta tehtäessä voidaan hyödyntää myös tutkimuksia, kyselyitä ja strukturoituja haastatteluja. Tavoitteita voivat olla luomassa myös perhe, läheiset tai moniammatillinen tiimi (Sukula Et Vainiemi 2015, 13-14). Maahanmuuttajaryhmien kanssa voidaan kehittää tukimenetelmiä, kuten erilaisia lauseiden täydentämistehtäviä tai tavoite-esimerkkilistoja (Pikkarai- 
nen Ct Kantanen 2015, 108). Yhtenä mahdollisuutena on harjoitella tuettua päätöksentekoa, joka voisi olla sopiva tuen muoto tavoitteista keskusteltaessa. Tuetussa päätöksenteossa kehitysvammaiselle henkilölle annetaan apua ja tukea päätösten ja valintojen tekemiseen. Tarkoituksena on rohkaista ja kannustaa päätöksenteossa omaa elämää koskevissa asioissa. (Terveyden ja hyvinvoinnin laitos 2015.) Voidaan hyödyntää tarkastuslistaa, jonka avulla tarkistetaan asetettujen tavoitteiden kohdalta, ettei ole sorruttu tyypillisiin virheisiin tavoitteita asetettaessa, mittaria valittaessa ja asteikkoa laadittaessa (Cardillo \&t Choate 1994, 19).

\section{Asiakas- ja yksilölähtöisyyden lisääntyminen parantaa laatua}

Ohjaajille syntyi käyttökokeilusta runsaasti ajatuksia GAS-menetelmän hyödyntämisestä tai käyttöönotosta työllistymistä ja osallisuutta edistävissä palveluissa. Eniten ajatuksia herättivät resurssit. Ohjaajat pohtivat, kuinka ajankäyttö, koulutus ja perehdytys sekä tukimuodot tulee järjestää. Asiakastietojärjestelmän integraatio ja esimiehen rooli tulee huomioida käyttöönotossa. Yhteistyö tiimin sisällä ja verkostoissa vaatii myös huomiota.

Ohjaajat kertoivat, ettei nykyiseen palveluiden toteuttamissuunnitelman yhteydessä tehtävään tavoitteen asetteluun olla tyytyväisiä. GAS-menetelmä tuntui paremmalta kuin nykyinen käytäntö asettaa ja arvioida tavoitteita. Seuraavaksi onkin olennaista yhdessä pohtia, miten, milloin ja keiden kanssa menetelmä otettaisiin käyttöön ja olisiko se suositeltava vai pakollinen työkalu. Tutkimuksen tulosten mukaan pakollisuudella olisi käyttöönottoon negatiivisia vaikutuksia.

Tulosten mukaan GAS:n käyttöönotto parantaisi palvelujen imagoa Rinnekoti-Säätiön sisällä sekä antaisi ulospäin hyvän ja luotettavan kuvan. Laatu kehittyisi nimenomaan asiakas- ja yksilölähtöisyyden lisääntymisen kautta.

\section{Eettisiä kysymyksiä}

Syvästi kehitysvammaisten palvelunkäyttäjien kanssa työskentelevät ohjaajat kävivät vahvaa eettistä pohdintaa. Ohjaajat prosessoivat, onko oikeutettua asettaa tavoitteita toisen puolesta. Pohdittiin myös ohjaajien vallankäyttöä, asiakaslähtöisyyden unohtumista ja kohtaamisen katoamista. Mietittiin, onko numeerinen arviointi hyväksyttävää ja voivatko ohjaajat alitajuisesti vääristellä saavutettuja tuloksia. Eettisten kysymysten kohdalla tuleekin käydä keskustelua sekä yksiköiden sisällä että tuoda keskustelu säätiön eettiseen lautakuntaan.

\section{GAS-klinikka osana käyttöönottoprosessia}

Tutkimusprosessin johtopäätöksinä esitetään, että GAS-menetelmä on selkeä, tunnettu ja luotettavaksi osoitettu asiakaslähtöinen työkalu, jonka käyttöönottoa Rinnekoti-Säätiössä kannattaa harkita. Käyttöönotossa olisi tärkeää hyödyntää tutkimuksessa kerättyjä ohjaajien ajatuksia ja kokemuksia. Tulosten pohjalta on laadittu ehdotus käyttöönottoprosessista. Se sisältää vaiheet kokeilun jatkamisesta ja vakinaistamisesta, avointen kysymysten ratkaisemisesta, tutkimuksen esittämisestä ja tiedottamisesta sekä GAS-menetelmän kehittämisestä Rinnekoti-Säätiössä. Yhtenä toimenpide-ehdotuksena on kertaalleen koulutuksen jälkeen pidetty GAS-klinikka. Klinikan toiminta-ajatus heräsi artikkelista "Mikä GAS-menetelmässä työvälineenä haastaa ja mikä tuntuu helpolta?” (Turunen, Hannonen Ct Ylisassi 2015). Alkuperäisen idean mukaisesti klinikka toimii perehdyttämisen ja reflektoinnin oppimisympäristönä. Aiheen parissa työskentelyä jatketaan myös vastaperustetussa vaikuttavuustyöryhmässä, jonka tehtävänä on pohtia palvelujen vaikuttavuutta ja laatia ehdotus sen arvioimiseksi RinnekotiSäätiössä.

Anna Eskola, esimies, Rinnekoti-Säätiö, sosionomi, Metropolian YAMK-opiskelija

Pirjo Knuuttila, lehtori, fysioterapeutti, TtM, Lahden ammattikorkeakoulu

Leena Hannula, lehtori, TtT, Metropolia ammattikorkeakoulu 


\section{Lähteet}

Autti-Rämö I (2010) GASin käyttöönotto. Teoksessa I Autti-Rämö, K Vainiemi, S Sukula, A Louhenperä (toim.) GAS-käsikirja, versio 2. Verkko-dokumentti >http://www.kela.fi/gasmenetelma?inheritRedirect $=$ true $<$ Luettu 31.10.2015. 16-18.

Cardillo JE, Choate RO (1994) Illustrations of Goal Setting. Teoksessa TJ Kiresuk, A Smith, JE Cardillo (toim.) Goal Attainment Scaling: Applications, Theory, and Measurement. Hillsdale, N.J.: L. Erlbaum Associates. 15-37.

Eskola A (2016) GAS-menetelmän käyttöönottokokemukset Rinnekoti-Säätiön Työllistymistä ja osallisuutta edistävissä palveluissa. Opinnäytetyö YAMK. Helsinki: Metropolia. Sosiaali- ja terveysalan johtamisen ja kehittämisen koulutusohjelma.

Kela (2016) GAS-menetelmä Kelan kuntoutuksen tavoitteiden laatimiseen ja arviointiin. Verkkodokumentti <www.kela.fi/gas-menetelma> Luettu 20.9.2016.

Kehitysvammaliitto (2014) TOIMI - menetelmä toimintakyvyn kuvaamiseen. Verkkodokumentti. <http:// www.kehitysvammaliitto.fi/suomeksi/tutkimus/ tutkimushankkeet/aikaisemmat-tutkimushankkeet/toimi-menetelma-toimintakyvyn-kuvaamiseen/> Luettu 16.2.2016.

Laukkala J, Tuomi J, Sukula S (2015) GAS-menetelmän taustaa. Teoksessa S Sukula, K Vainiemi, T
Laukkala (toim.) GAS Menetelmästä sovellukseen.

Tampere: Kelan tutkimusosasto.11-13.

Pikkarainen A, Kantanen M (2015) Kuntoutuksen tavoitteiden laatiminen erilaisissa kuntoutusmuodoissa ja elämäntilanteissa: Ikääntyneiden asiakkaiden tavoitteet gerontologisessa kuntoutuksessa. Teoksessa GAS - Menetelmästä sovellukseen. Tampere: Kelan tutkimusosasto. 99-116.

Puhakka S (2015) GAS-menetelmän käyttöönoton kokeilu Honkalampi-keskuksessa. Opinnäytetyö YAMK. Joensuu: Karelia Ammattikorkeakoulu. Sosiaali- ja terveysalan kehittämisen ja johtamisen koulutusohjelma.

Sallinen M, Bärlund E, Koivuniemi M, Heinonen T (2015) Kohti yhteisiä tavoitteita. GAS-koulutuksen arviointihankkeen loppuraportti. Työpapereita 79, Kelan tutkimusosasto. Helsinki.

Smith A (1994) Chapter 1 - Introduction and Overview. Teoksessa T J Kiresuk, A Smith, J E Cardillo (toim.) Goal Attainment Scaling: Applications, Theory, and Measurement. Hillsdale, N.J.: L. Erlbaum Associates. 1-14.

Sukula S, Vainiemi K (2015) Gas-menetelmä (Goal attainment scaling) Tavoitteiden laatiminen. Teoksessa S. Sukula, K Vainiemi, T Laukkala (toim.) GAS - Menetelmästä sovellukseen. Tampere: Kelan tutkimusosasto. 13-15.

Terveyden ja hyvinvoinnin laitos (2015) Vammaispalvelujen käsikirja. Tuettu päätöksenteko. Verkko-
Rinnekoti-Säätiö tuottaa asiantuntevia sosiaali- ja terveydenhuollon sekä opetustoimen palveluja erityisesti kehitysvammaisille henkilöille. Rinnekoti-Säätiön arvot lähimmäisyys, asiantuntijuus ja hyvä elämä ovat toiminnan perusta. Palveluja tuotetaan arvojen ja asiakkaiden yksilöllisten tarpeiden pohjalta.

Rinnekoti on palveluiltaan Suomen monipuolisin kehitysvamma-alan toimija, jonka asiantuntemus vaativimmissa palveluissa on tunnustettu. Säätiö monipuolistaa palvelujaan jatkuvasti pitäen samanaikaisesti huolta perustehtävästään erityispalveluja tarvitsevien ja vaikeimmin vammaisten hoitopaikkojen saatavuudesta.
Toiminta Rinnekoti-Säätiössä perustuu eri laeissa yksityisille palveluntuottajille annettuun oikeuteen tuottaa palveluja kuntayhtymille, kunnille tai muille palveluja haluaville. Säätiö palvelee Uudellamaalla sekä valtakunnallisesti.

Yksi tuotettujen palveluiden muoto on työllistymistä ja osallisuutta edistävät palvelut, aiemmin työ- ja päivätoimintapalvelut. Työllistymistä ja osallisuutta edistävien palveluiden sisältö koostuu palvelunkäyttäjän tavoitteiden, tarpeiden ja mielenkiinnon kohteiden mukaan suunnitellusta yksilöllisestä päivästä ja pohjautuu palveluiden toteuttamissuunnitelmaan ja toimintakykyarviointiin.

Lisätietoa: www.rinnekoti.fi 
dokumentti. < https://www.thl.fi/fi/web/vammaispalvelujen-kasikirja/palvelujen-jarjestamisprosessi/tuettu-paatoksenteko> Päivitetty 29.7.2015. Lu-ettu 8.8.2016.

Tuomi J (2014) Kyselytutkimus fysio- ja toimintaterapeuteille GAS-menetelmän käyttökokemuksista. Pro gradu -tutkielma. Jyväskylä: Jyväskylän yliopisto. Liikuntatieteellinen tiedekunta. Terveystieteiden laitos.

Turunen J, Hannonen K, Ylisassi H (2015) Mikä GASmenetelmässä työvälineenä haastaa ja mikä tuntuu helpolta? Teoksessa S Sukula, K Vainiemi, T Laukkala (toim.) GAS - Menetelmästä sovellukseen. Tampere: Kelan tutkimusosasto, 117-123.

Ylisassi H (2012) GAS-menetelmän (Goal Attainment Scaling) käyttö ammatillisessa (työhön liittyvässä) koulutuksessa. Tutkimus- ja kehittämishanke Aslak -kuntoutuksessa. Hankkeen jatko-osa 20112012. Hankeraportti. Verkkodokumentti. <http:// www.kela.fi/documents/10180/12149/gas_kokeiluhanke_jatkoraportti_hy_29.3.pdf.> Luettu 10.8.2016.

\section{kuntoutusportti.fi}

\section{Kuntoutustiedon kokoava portaali}

Kuntoutusportti on kuntoutuksen maksuton verkkopalvelu, joka sisältää uutisia, tapahtumia, artikkeleja ja näkökulmia.

Tutkimus- ja hanketietokanta sisältää Suomessa julkaistuja kuntoutuksen verkkojulkaisuja, tutkimuksia ja hankkeita.

Kuntoutusportin uutiskirje kokoaa yhteen ajankohtaiset asiat ja tapahtumat. 